\title{
Transition from e-Government to m-Government: Challenges and Opportunities - Case Study of UAE
}

\author{
Badir Yousif Rafee Alharmoodi \\ Muhammad Modi B. Lakulu \\ Associate Professor Dr. Faculty of Management \& Economics, University of Pendidikan Sultan Idris, Tanjung Malim. \\ Malaysia
}

\begin{abstract}
This study aims to explore the challenges of the transition from e-government to m-government as well as to identify and develop a workable framework on m-government standards, protocols and its inherent opportunities for various business engagements. The objectives of the study are to identify strategic challenges in various government organizations that impede transition from e-government services to m-government services, formulate a framework of m-government for government and private business organizations to tackle the challenges and enhance the opportunities using Fuzzy Delphi method, and to validate the proposed framework using Fuzzy Delphi method. A survey questionnaire is used to gather data on the study constructs. The validation of formulated framework is based on Fuzzy Delphi method. Descriptive statistics is used to determine the frequency of the demographical variables. Independent sample T-test is used to test the hypothesis in other to show the variance in the constructs against the dependent variable. This study has identified through systematic literature review five (5) categories of challenges and opportunities.
\end{abstract}

Keywords: e-Government, m-Government, mobile government, challenges and opportunities.

\section{Introduction}

e-Government plays a major role of information dissemination to the public thereby facilitating implementation of government services, transactions, policy implementation and resource distribution across agencies which results in agencies experiencing cost reductions and improved efficiency, while citizens receive faster, more convenient services (Trinkle, 2001). Adoption and implementation of E-government in UAE though faced with challenges and barriers became increasingly relevant to providing a superior flow of information delivery of government services. In the recent years, the public, as well as government employees deployed at various organizations, have witnessed the proliferation of mobile devices. This has resulted in the transition from e-government to m-government also known as (Mobile government) as more people are recognizing the importance of $\mathrm{m}$-government since mobile devices are readily available with them anytime and anywhere (Song, 2005; Pandey and Sekhar, 2013). Transition to M-government became imminent as the rate of mobile phone penetration across the Emirates was on record high (Al-Khouri, 2012).

M-Government which is defined as the extension or evolution of e-government through utilization of mobile technologies for public service delivery (Oui-Suk, Uhm , 2010).

\section{Problem Statement}

The transition from e-government to m-government has also posed some challenges (Sharma \& Gupta 2004; Song 2005; Weerakkody et al., 2007). Many of these challenges to total implementation have both social and technical dimensions ranging from people awareness, privacy of information, data security, trust, and technology training skills (Abu Tair \& Abushanab, 2014; Al-Shboul, et, al. 2014; Qader \& Kheder, 2016. Some authors have also outlined some challenges to include; cultural, political, structural, legal as well as social and administrative (Abu-Shanab, 2012; Al-Thunibat et al. 2010; Fasanghari \& Samimi, 2009; El-Kiki \& Lawrence, 2007; Mukherjee \& Biswas, 2005; Antovski \& Gusev, 2005; Kim et al., 2004.). 
In 2015, the two-year deadline imposed by UAE government for m-government services to be implemented across all government organizations ended and a remarkable milestone of $96.3 \%$ implementation was reached in 337 most important government services. 41 government entities scored a milestone of above 90\% transformation, (Bernd DJ 2015). The research problem evoked considerable interest that warranted proper investigation into the challenges that most of the government entities encountered and some of the barriers that hindered their complete transition from E-government to Mgovernment within the given time frame of transition and beyond. This study, therefore, focused on exploring these challenges as well as identifying ways to evaluate the framework on m-government standards, protocols and its inherent opportunities for various business engagements.

\section{Literature review}

Visions of sustainable development have led many nations around the world to strategized different methods to develop strong Information Communication Technologies (ICT) infrastructure to boast services delivery and increase economic growth. The modern era is seen to revolve around a digitized society which has great potential to impart both social and economy status of citizens. Such significant impacts on the economy and society includes economic growth, job creation, increase in productivity, poverty reduction, increase in accessibility to quality healthcare and education as well as reduction in environmental pollution as shown in Table 2.1 (World Bank "World Development Report 2016). ICT is a powerful tool to facilitate developmental goals acting as a strong enabler that improves communication and knowledge sharing (UN Millennium Project, 2005).

\begin{tabular}{|l|l|l|l|}
\hline DIGITAL IMPACT & \multicolumn{2}{|l|}{ Social } \\
\hline Economic & $\begin{array}{l}\text { Increased digital penetration has } \\
\text { a substantial impact on economic } \\
\text { growth }\end{array}$ & Poverty & $\begin{array}{l}\text { Experience in countries such as Bolivia } \\
\text { and India show that digital can be a tool } \\
\text { for inclusion and increased income among } \\
\text { the disadvantaged }\end{array}$ \\
\hline Job creation & $\begin{array}{l}\text { Digital has a powerful multiplying } \\
\text { effect: international cases show that } \\
\text { each digital job creates 2-4 jobs } \\
\text { elsewhere in the economy. } \\
\text { Moreover, those are high-value jobs } \\
\text { (wages 30\% above average) }\end{array}$ & $\begin{array}{l}\text { Healthcare } \\
\text { E-health enables new forms of healthcare } \\
\text { management and provision, increasing } \\
\text { patient coverage and improving quality }\end{array}$ \\
\hline Productivity & $\begin{array}{l}\text { productivity } \\
\text { Increases SMEs that make better } \\
\text { use of digital grow faster }\end{array}$ & $\begin{array}{l}\text { Digital has a powerful multiplying } \\
\text { effect: international cases show that } \\
\text { each digital job creates 2-4 jobs } \\
\text { elsewhere in the economy. } \\
\text { Moreover, those are high-value jobs } \\
\text { (wages 30\% above average) }\end{array}$ & Environment \\
\hline Job creation & $\begin{array}{l}\text { Education } \\
\text { contribution to the environment: (it might } \\
\text { contribute with 15\% reduction in CO2 } \\
\text { emissions, for example, by using smart } \\
\text { grids) }\end{array}$ & $\begin{array}{l}\text { Education can be provided to the masses } \\
\text { at low cost and good quality, using e- } \\
\text { education tools }\end{array}$ \\
\hline
\end{tabular}

ICTs also play a critical role in speeding up the flow of information and knowledge between government and citizens and transforming the way in which governments and citizens interact (Castells, 2009; Varian et al., 2005).

The ultimate goal of E-governance is to reach the society with efficient services for business economic growth, modernized government services, transparency in government and maintaining a stable democratic governance (Atkinson \& Castro, 2008). Electronic Governance is the application of technology by government to transform itself and its interactions with customers, in order to create impact on the society (Estevez \& Janowski, 2013). 


\section{E-government in UAE}

The initiative launched in 2001 focused on three distinctive categories (eServices- for the provision of efficient quality electronic mediated services aimed at meeting customer's needs); (eReadiness - for strengthening the ability of federal government entities to handle the needed technology, coordination and human resource management) and ICT management focusing on infrastructure, training and policy implementations (Al-Khouri, 2012). As shown in Table 2.3, UAE ranked $29^{\text {th }}$ in UN development Index in terms of E-participation indicating a strong push for digitalized government service delivery and governance in general across the emirates.

As stresses by Hassan, Jaber, and Hamdan (2009), there is a solid connection between e-government and m-government strategies. As further pointed out by Abdelghaffar and Yousra (2012), the fundamental reason that impact the transition from e-government to m-government are proliferation of cell phones in the UAE society as well as the appearance of versatile web and portable applications and administrations of mobile phones which has gathered momentum as compared with the conventional wired personal computers. This remarkable development has changed how nationals see the cell phones usefulness as citizen see further how mobile phone can not only be used for calling and interacting but as means for exchanging data, trading texts, and sending and receiving messages from government portals (Kushchu \& Kuscu, 2003).

\section{UAE Transition from E-government to M-government}

Proliferation of mobile device in the UAE is among the key factors that has revolutionized the electronic governance across the emirates. A report by Newzoo' Global Mobile Market (2017) placed UAE on the top list of countries with the highest smart phone penetration (80.6\%). (https://newzoo.com/insights/rankings/top-50-countries-by-smartphone-penetration-andusers/).

As a nation in the forefront of E-government adoption in the GCC, transition from E-government to M-government was imminent as emphasized in the government developmental vision of 2021.

The UAE initiated the strategic developmental plan to transit from E-government to M-government in 2013 with the ambitious goal to lead the world in excellence in mobile technology government through making every government service available on mobile phone which can be access 24 hours/7days within two year from its launching. A report in 2015 on the ambitious goal of UAE transition from E-government to M-government showed that 41 government entities reached a milestone success in transiting from website to mobile application service delivery covering 337 government services. Undoubtedly, Challenges were faced as many government entities especially the small one could not meet the dead line set by the government in 2015 .

This study aims to investigate the challenges and barriers as well as opportunities to successful implement M-government across all government and private entities in the emirates of Dubai, UAE. In so doing, the researcher carried out a systematic analysis of 70 papers as well as official newspaper publications, postgraduate dissertations and research publications for the period of 2012- 2018.

\section{Research Methodology}

A survey questionnaire will be used to gather data on the study constructs and the validation of formulated framework will be based on Fuzzy Delphi method. Statistical Package for Social Sciences (SPSS version 25) will be used for the encoding of data collected for analysis. Descriptive statistics will be used to determine the frequency of the demographical variables. Independent sample T-test will be used to test the hypothesis in other to show the variance in the constructs against the dependent variable. One-way ANOVA test will be used to show the variance amongst the framework variables. Multiple Regressions will be used to illustrate the challenges that influence the smooth transition from e-government to $\mathrm{m}$ government. Fuzzy Delphi Method will be used for framework formulation and Nominal Group Technique (NGT) will be employed for the validation of the framework.

\subsection{Research design}

In this study a quantitative research approach was employed to investigate and collect data on the construct concerning challenges, barriers an opportunity encountered in the process of transition from e-government to m-government service delivery of the emirate of Dubai, UAE. Data was gathered through self-administered survey questionnaire which sought 
opinions from involved government personnel in the implementation of m-government across established government institutions in the emirate of Dubai, UAE. The outcome of the data gathered generated interferences in answering the stated research questions and hypothesis.

\subsection{Framework formulation}

\begin{tabular}{|l|l|}
\hline Process & Methods \\
\hline Framework proposition & Analysis of prevailing framework and guidelines \\
\hline $\begin{array}{l}\text { Framework validation through survey } \\
\text { questionnaire (Fuzzy Delphi Method) }\end{array}$ & $\begin{array}{l}\text { Project assessment Framework proposed by Esteves and Joseph (2008) which } \\
\text { incorporates; Technological dimension, Strategic dimension, Organizational } \\
\text { dimension, Operational, services and economic assessment dimensions }\end{array}$ \\
\hline
\end{tabular}

\subsection{Population and sample size}

Burns and Grove (2003) identified research population as all the elements that meet the criteria for inclusion in a study.

In this study, the target population includes Dubai government employees as well as employees from private business establishments that are fully engaged in electronic and mobile government service delivery and transaction exchange. The total target population is estimated at 750 employees.

According to Polit et al (2001) a sample is "a proportion of a population". In this study the sample size includes employees from ten (10) government organizations and employees from ten (10) private business organizations in the emirate of Dubai, United Arab Emirates (UAE) with a total of 250 employees. Sample size was estimated base on the percentage of employees per organizations.

\section{Overview of Conceptual Framework}

\section{Independent Variables (Challenges)}

1. IT infrastructure - (Ndou, 2004; Sharma \& Gupta, 2003)

2. Security and Privacy - (Basu, 2004; Layton, 2007)

3. IT skills-(UNPA \& ASPA, 2001; Tair \& Abu-shanab, 2014; Al-Shboul, et, al. 2014)

4. Knowledge of operating standards and protocols

5. Operational framework - (UNPA \& ASPA, 2001; Qader \& Kheder, 2016)

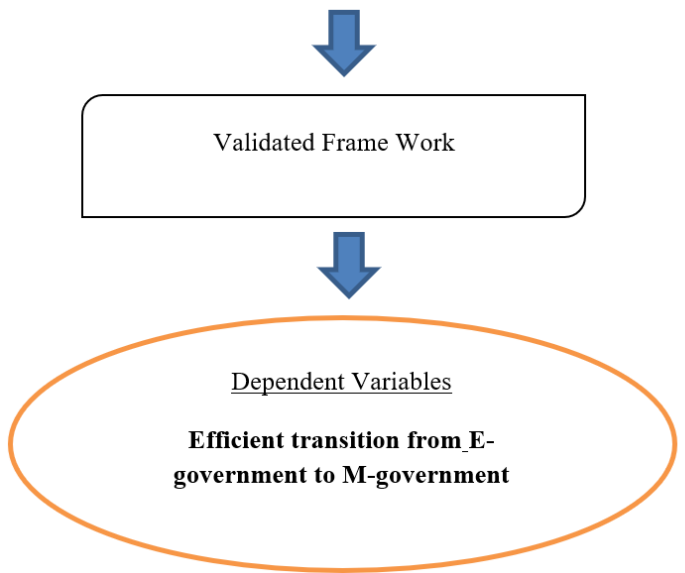




\section{Instruments (Questionnaire)}

The questionnaire was designed to better gather expert opinions on the challenges in the transition from e-government to m-government service delivery from government and private establishments in Dubai, UAE. The questionnaire consists of three (3) sections.

The first section is designed to gather demographic data of the respondents. The second section consists of questions to obtain professional opinions based on IT infrastructure, Skills and operational protocol. The third section consists of openended question base on trust, security and privacy. Questions were structured following a 4-point Likert scale (1. Strongly disagree, 2. Disagree, 3. Agree, 4. Strongly agree).

\begin{tabular}{|l|l|}
\hline Variable & No. of Items \\
\hline IT INFRASTRUCTURE & 5 \\
\hline IT SKILLS & 5 \\
\hline SECURITY, TRUST AND PRIVACY & 5 \\
\hline $\begin{array}{l}\text { KNOWLEDGE OF OPERATING STANDARD AND } \\
\text { PROTOCOLS }\end{array}$ & 5 \\
\hline OPERATING FRAMEWORK & 5 \\
\hline
\end{tabular}

\section{Data Analysis \& Result}

\begin{tabular}{|c|c|c|c|}
\hline No & Objectives & Methods & Data Analysis \\
\hline 1. & $\begin{array}{l}\text { To identify strategic challenges in various } \\
\text { government organizations that impede } \\
\text { transition from e-government services to } \\
\text { m-government services }\end{array}$ & $\begin{array}{l}\text { Systematic Review of Related } \\
\text { Literature }\end{array}$ & $\begin{array}{l}\text { Data Reliability Test } \\
\text { a) Cronbach Alpha }\end{array}$ \\
\hline 2. & $\begin{array}{l}\text { To formulate a framework of m- } \\
\text { government for government and private } \\
\text { business organizations to tackle the } \\
\text { challenges and enhance the opportunities } \\
\text { using Fuzzy Delphi method }\end{array}$ & $\begin{array}{l}\text { a) Research title and research } \\
\text { problem. } \\
\text { b) Review of related literature } \\
\text { c) Listing of constructs }\end{array}$ & Descriptive Statistics \\
\hline 3. & $\begin{array}{l}\text { To validate the proposed framework using } \\
\text { Fuzzy Delphi method }\end{array}$ & $\begin{array}{l}\text { Fuzzy Delphi Method } \\
\text { (Expert opinion through Survey } \\
\text { questionnaire) }\end{array}$ & $\begin{array}{l}\text { a) Normal Curve distribution } \\
\text { b) Hypothesis Testing } \\
\text { - Independent sample } \\
\text { T-test } \\
\text { - ANOVA } \\
\text { - Multiple Regression }\end{array}$ \\
\hline
\end{tabular}

\section{Conclusion}

This study facilitated the formulation of the study framework regarding the challenges and opportunities of transition from e-government to m-government. Through the process of screening and reading the main text of journal articles five (5) categories were identified which constituted the study constructs. In this study, the findings show that the independent variables (IT Infrastructure; Security, Trust and Privacy; IT Skills; Challenges of Organization Coordination; Knowledge of Operating Standard and Protocols; Operating Framework) are significant for an efficient transition from e-government to m-government). The findings show that the independent variables (IT Infrastructure; Security, Trust and Privacy; IT Skills; Challenges of Organization Coordination; Knowledge of Operating Standard and Protocols; Operating Framework) are significant for an efficient transition from e-government to m-government). 


\section{References}

[1] Abdelghaffar, H. and Magdy, Y. (2012). The Adoption of Mobile Government Services in Developing Countries: The Case of Egypt. International Journal of Information and Communication Technology Research, 2(4), pp. 333-341

[2] Abu-Shanab, E. (2012). Digital Government Adoption in Jordan: An Environmental Model. The International Arab Journal of e-Technology (IAJeT), Vol. 2(3) January 2012, pp. 129-135.

[3] Al-Khouri, A. M. (2012). eGovernment strategies the case of the United Arab Emirates (UAE). European Journal of ePractice, 17, 126-150.

[4] Al-Shboul, M., Rababah, O., Ghnemat, R., \& Al-Saqqa, S. (2014). Challenges and factors affecting the implementation of e-government in Jordan. Journal of Software Engineering and Applications, 7(13), 1111.

[5] Al-Thunibat, A., Zin, N. A. M., \& Ashaari, N. S. (2010). Mobile government services in Malaysia: Challenges and opportunities, International Symposium on Information Technology (ITSim), IEEE, Vol. 3, pp. 1244-1249.

[6] Antovski, L., \& Gusev, M. (2005). M-Government Framework, Proceedings of the First European Conference on Mobile Government, pp. 36-44. Arabian Gulf: a vision toward reality. In Proceedings of the 2003.

[7] Atkinson, R.D. \& Castro, D.D. (2008). Digital Quality of Life: Understanding the Personal and Social Benefits of the Information Technology Revolution, Information Technology and Innovation Foundation, 137-145, retrieved March 10, 2012 from available at: www.itif.org/files/DQOL.pdf.

[8] Bernd DJ (2015) 96.3\% marks for m-government initiative in 41 entities. Retrieved 27 July 2015 from Khaleej Times http://www.khaleejtimes.com/nation/government/96.3-marks-for-m-government-initiative-in41-entities

[9] Burns, N., \& Grove, S. K. (2001). Introduction to qualitative research. The practice of nursing research. Conduct, critique and utilization (, 67-68.

[10] Castells, M. (2009). The Rise of the Network Society: The Information Age - Economy, Society, and Culture, volume I, second edition, Chichester: John Wiley \& Sons.

[11] El-Kiki, T., \& Lawrence, T. (2007). Emerging Mobile Government Services: Strategies for Success, 20th Bled eConference, eMergence: Merging and Emerging Technologies (pp. 1-12). Processes, and Institutions

[12] Estevez, E., \& Janowski, T. (2013). Electronic Governance for Sustainable Development-Conceptual framework and state of research. Government Information Quarterly, 30, S94-S109.

[13] Fasanghari, M., \& Samimi, H. (2009). A Novel Framework for M-Government Implementation, International Conference on Future Computer and Communication (ICFCC), IEEE, pp. 627-631.

[14] Hassan M, T, Jaber T and Hamdan. Z (2008). "Adaptive mobile-government framework," in Proceedings of the International Conference on Administrative Development: Towards Excellence in Public Sector Performance,

[15] Kim, Y., Yoon, J., Park, S., \& Han, J. (2004). Architecture for implementing the mobile government services in Korea (pp. 601-612). Conceptual Modeling for Advanced Application Domains. doi:10.1007/978- 3-54030466-1_55

[16] Kushchu. I and Kuscu. H (2003). "From E-government to M-government: Facing the Inevitable," In the 3rd European Conference on e-Government, MCIL Trinity College Dublin Ireland

[17] Mukherjee, A., \& Biswas, A. (2005). Simple implementation framework for m-government services, International Conference on Mobile Business (ICMB), IEEE, pp. 288-293.

[18] Newzoo's Global Mobile Market Report, (2017). Retrieved from: https://newzoo.com/insights/rankings/top-50countries-by-smartphone-penetration-and-users/

[19] Oui-Suk, U. (2010), "Introduction of m.Government \& IT Convergence Technology", working document, KAIST Institute for IT Convergence, Daejeon, Republic of Korea.

[20] Pandey. K. R., and K. S. V. Sekhar, (2013) "From e-Governance to m-Governance: The way forward," e-Gov Technological Framework, pp. 1-9

[21] Polit, D.F., Beck, C.T. and Hungler, B.P. (2001), Essentials of Nursing Research: Methods, Appraisal and Utilization. 5th Ed., Philadelphia: Lippincott Williams \& Wilkins

[22] Song, G. (2005) "Transcending e-Government: a case of mobile government in Beijing", The First European Conference on Mobile Government, Brighton

[23] Sharma and J. Gupta, "Web services architecture for m-government: issues and challenges", Electronic Government, an International Journal, Vol.1, no. 4, pp.462-474, 2004 
[24] Tair, H. Y. A., \& Abu-Shanab, E. A. (2014). Mobile Government Services: Challenges and Opportunities. International Journal of Technology Diffusion (IJTD), 5(1), 17-25.

[25] Trinkle, S. (2001) Moving citizens from in line to online: how the internet is changing how government serves its citizens. 30 September 2001. [WWW document]. URL http:// www.bcinow.com/demo/oel/Resources_Articles.htm

[26] Weerakkody, V., Janssen, M \& Hjort-Madsen, K. (2007) Integration and Enterprise Architecture Challenges in E-Government: A European Perspective. International Journal of Cases on Electronic Commerce, 3, 13-35.

[27] Qader, N. N., \& Kheder, M. Q. (2016). Challenges and Factors affecting the implementation of e-Government in Iraq. Journal of University of Human Development/Vol, 2(3).

[28] UN Millennium Project (2005) Innovation: Applying Knowledge in Development. UN Task Force on Science, Technology, and Innovation, New York.

[29] Varian, H.R., Farrell, J. \& Shapiro, C. (2005). The Economics of Information Technology. New York: Cambridge University Press.

[30] World Bank "World Development Report 2016: Digital Dividends", 14 January 2016 World Bank, Digital Adoption Index 2016 